\title{
Preservation of peptide moieties in three Spanish sulfur-rich Tertiary kerogens
}

\author{
Jos\& C. del Rlo ${ }^{a, *}$, M.A. Olivella ${ }^{b, 1}$, Heike Knicker ${ }^{c}$, F. Xavier C. de las Heras ${ }^{b}$
}

\begin{abstract}
Thermochemolysis with tetramethylammonium hydroxide (TMAH) and solid-state ${ }^{15} \mathrm{~N}$ NMR were utilized for the characterization of refractory organic nitrogen in Tertiary Spanish kerogens. The samples included sulfur-rich oil shales from the Ribesalbes (Serravallian), Libros (Tortonian) and Cerdanya (Tortonian) basins. Analysis using solid state ${ }^{15} \mathrm{~N}$ NMR showed that part of the refractory nitrogen in the kerogens corresponds to amide groups. Moreover, the release of amino acid derivatives after pyrolysis in the presence of TMAH indicated that this amide-N arose from peptide moieties. The amino acids released from the kerogens were dominated by high amounts of glycine and alanine. Minor amounts of aspartic acid, serine, a-aminobutyric acid and other unidentified amino acids were also detected. Because proteinaceous structures, including small peptides, are generally considered as being highly sensitive to diagenetic degradation, encapsulation of labile peptide material into aliphatic structures in S-rich kerogens (probably via lipid sulfurization) has been proposed to explain the survival of these moieties. Substantial amounts of fatty acids (as methyl esters) were also released from all the kerogens after pyrolysis/TMAH, indicating their highly aliphatic character. The production of both fatty acids and amino acids from the kerogens supports the encapsulation process.
\end{abstract}

! 2004 Elsevier Ltd. All rights reserved.

\section{Introduction}

Nitrogen is an importan component that influences the cycling of organic matter in the biosphere. However, the nature of nitrogen in geochemical samples is far from clear. Nitrogenous compounds in living organisms exist mainly as complex molecular structures known as protein, made up of various combinations of 20 aminoacids. Proteins are highly sensitive to degradation and until recently, the fate of peptides during diagenesis was considered to be either total remineralization or random recocmbination with other degraded biomolecules to yield heterocyclic moieties (patience et al., 1992; Schulten and Schnitzer, 1997). However, recent studies using solid-state $15 \mathrm{~N}$ MR and thermochemolysis with tetramethylammonium hydroxide (TMAH) have shown that part of the nitrogen-containing materials in refractory organic matter form several sediments corresponds to peptide material that survived microbial degradation (Knicker and Hatcher, 1997; Zang et al., 2000; Knicker, 
2000; Garcette-Lepecq et al., 2001; Knicker et al., 2001). Some authors have suggested that encapsulation of labile nitrogen-containing materials into refractory organic matter can partly explain the fate of proteinaceous materials in biogeochemical deposits (Knicker and Hatcher, 1997; Zang et al., 2000; Knicker et al., 2001; Nguyen and Harvey, 2003; Nguyen et al., 2003). Recently, Riboulleau et al. (2002) also suggested that encapsulation into aliphatic sulfurized material was probably the major process for amino acid preservation in kerogens with a high sulfur content.

Traditionally, wet chemical methods have been applied to the characterization of nitrogenous materials in natural organic matter (Huang et al., 1993). More recently, the use of solid-state ${ }^{15} \mathrm{~N}$ NMR for studying different types of organic matter in geochemical samples has shown the importance of amide functional groups, probably from peptides and proteins, among the refractory organic nitrogen in sediments (Knicker and Hatcher, 1997; Derenne et al., 1998; Knicker et al., 2001). Pyrolysis techniques have also proven valuable for obtaining detailed molecular information about macromolecular organic matter. The pyrolysis of polar macromolecular materials is known to produce volatile polar products, only some of which can be chromatographed; polar products remain attached to the column, undetected and unquantified. Pyrolysis in the presence of TMAH derivatizes polar compounds to become less polar products, which are more amenable to chromatographic separation (Challinor, 1989; del Rlo et al., 1996). This technique, and the off-line version have been widely used in the analysis of different biopolymers and geomacromolecules (de Leeuw and Baas, 1993; SaizJimbnez, 1994; Clifford et al., 1995; Mart!n et al., 1994; del Rlo et al., 1995, 1996, 1998; del Rlo and Hatcher,

1998). This method has also been shown to cleave peptide bonds efficiently (Knicker et al., 2001; Knicker and Hatcher, 1997; Zang et al., 2000). The technique has been successfully applied to the analysis of protein-derived materials in biopolymers and geomacromolecules (Knicker and Hatcher, 1997; Zang et al., 2000; Knicker et al., 2001; Mongenot et al., 2001; Riboulleau et al., 2002).

Recently, the release of amino acids upon TMAH treatment of the methanol-eluted, non-acid fraction of the pyrolysate of a $140 \mathrm{Ma}$ old S-rich kerogen has been reported (Mongenot et al., 2001; Riboulleau et al., 2002). These papers confirmed a major role of encapsulation into aliphatic structures for the survival of proteinaceous materials in highly aliphatic S-rich kerogens, probably via lipid sulfurization.

In the present paper, we use solid-state ${ }^{15} \mathrm{~N}$ NMR and pyrolysis in the presence of TMAH in order to characterize the nature of the refractory organic nitrogen in three Tertiary Spanish S-rich kerogens. Until now, amino acids have been found in a polar off-line pyrolysate of a kerogen (Riboulleau et al., 2002). However, to the best of our knowledge, identification of amino acids derivatives by direct TMAH treatment of the kerogen has not been reported.

\section{Material and methods}

\subsection{Description of samples}

Three kerogens from Tertiary lacustrine systems, corresponding to the Ribesalbes (Serravallian), Cerdanya (Tortonian) and Libros (Tortonian) basins, were selected. Ribesalbes oil shales were deposited during the Middle Miocene (Serravallian; Anadon et al., 1989); they are immature and calcareous in origin. The Ribesalbes lacustrine system evolved in an intermediate sized, extensional basin (up to $150 \mathrm{~km}^{2}$ ) in the $\mathrm{SE}$ Iberian Range (Anadon et al., 1989; Anadon and Roca, 1996). Mesozoic limestones, red bed units and evaporites (mainly Upper Triassic gypsum) make up the source areas of the basin. The Cerdanya oil shale was deposited during the Late Miocene (Tortonian). It is a mudstone which is considered an anapaite vein because of the high amount of phosphorous (15\% $\mathrm{P}_{2} \mathrm{O}_{5}$ ) that appears in the diatomaceous lacustrine unit. Rare bioturbation and fine laminations as well as good fossil preservation are also the main characteristics of this sedimentary unit, which is similar to the Eocene Messel Oil Shale (de las Heras et al., 1989). The Late Miocene Libros lacustrine system evolved within the large (up to $2500 \mathrm{~km}^{2}$ ) Early Miocene-Early Pleistocene Teruel basin in the SE Iberian Range (Anadon and Roca, 1996). The source areas of the basin consisted mainly of Mesozoic limestones and Triassic gypsum, with minor siliciclastics (mudstones and sandstones).

\subsection{Kerogen preparation and elemental analysis}

The kerogen concentrates were prepared by treatment of the powdered, dichloromethane pre-extracted, oil shales with $\mathrm{HCl} / \mathrm{HF}(1: 1)$. The kerogens were subsequently washed four times with double-distilled water and re-extracted (3!) with dichloromethane:methanol (3:1) by sonication, according to Simoneit et al. (1986).

Elemental analysis of the isolated kerogens was carried out to determine total organic carbon and hydrogen, using a Fisons 1108 elemental analyzer. Organic sulfur was measured according to the ASTM D2492-90 method where wet treatment was used to determine pyritic and sulfate forms directly. Total sulfur was measured using elemental analysis with an elementary analyzer (Carlo Erba 1106) and organic sulfur was obtained as the difference between total sulfur minus pyritic and sulfate sulfur. The results revealed that 
Table 1

Bulk features of isolated kerogens

\begin{tabular}{lllllllrr}
\hline Kerogen & $\% \mathrm{C}$ & $\% \mathrm{H}$ & $\% \mathrm{~N}$ & $\% \mathrm{~S}$ & $\mathrm{H} / \mathrm{C}$ & $\mathrm{N} / \mathrm{C}$ & $\mathrm{S}_{\text {org }} / \mathrm{C}$ & $(\mathrm{Gly}+\mathrm{Ala}) / \mathrm{FaC}$ \\
16
\end{tabular}

${ }^{\text {a }}$ Estimated from pyrolysis in the presence of TMAH.

Ribesalbes kerogen is extremely rich in organic sulfur (atomic $\mathrm{S}_{\text {org }} / \mathrm{C}$ ratio $>0.04$ ) and hydrogen (atomic ratio $\mathrm{H} / \mathrm{C}$ ratio $>1.5$ ) and is classified as a Type I-S kerogen (Table 1). The Cerdanya kerogen, although with a lower atomic $\mathrm{H} / \mathrm{C}$ ratio, is still considered an immature Type I kerogen in the van Krevelen diagram. Libros kerogen, on the other hand, has the lowest atomic ratio $\mathrm{H} /$ $\mathrm{C} 1 / 41.51$, and is therefore classified as a Type I kerogen. Although its $\mathrm{S}_{\text {org }} / \mathrm{C}$ ratio (0.016) is the lowest, the total sulfur content gives an atomic ratio $\left(\mathrm{S}_{\text {tot }} / \mathrm{C} 1 / 40.071\right)$ for the whole rock oil shale and the soluble fraction contains high amounts of organosulfur compounds.

\subsection{Pyrolysis in the presence of TMAH}

Pyrolysis in the presence of TMAH was performed with approximately $100 \mathrm{Ig}$ sample in finely powdered form, deposited on to a ferromagnetic wire and mixed with $0.511 \mathrm{TMAH}(25 \% \mathrm{w} / \mathrm{w}$ aqueous solution). The wire then was inserted into a glass liner, which was placed in the pyrolyser. Pyrolysis was carried out with a Varian Saturn $2000 \mathrm{GC}-\mathrm{MS}$, using a $30 \mathrm{~m} ! 0.25 \mathrm{~mm}$ DB-5MS column (film thickness $0.25 \mathrm{1m}$ ), coupled to a Curie-point pyrolyser (Horizon instruments Ltd.). Pyrolysis was carried out at 610 "C. The temperature of the chromatograph oven was programmed to rise from 40 "C $(1 \mathrm{~min})$ to $300 " \mathrm{C}$ at a rate of $6{ }^{\mathrm{N}} \mathrm{C} \min ^{\# 1}$; the final temperature was held for $20 \mathrm{~min}$. The injector, equipped with a liquid carbon dioxide cryogenic unit, was pro- grammed from $) 30$ "C (1 min) to 300 "C at $200 " \mathrm{C} \mathrm{min} \# 1$, while the $\mathrm{GC}-\mathrm{MS}$ interface was kept at 300 "C. The amino acids were identified by comparing the mass spectra (obtained at $70 \mathrm{eV}$ ) with those of the Wiley and NIST computer libraries and with previously pub- lished mass spectra (Knicker et al., 2001). Blank exper- iments were performed to rule out the possibility of contamination.

\subsection{Solid-state ${ }^{15} \mathrm{~N}$ NMR spectroscopy}

The solid-state CPMAS ${ }^{15} \mathrm{~N}$ NMR spectra were obtained using a Bruker DMX 400 operating at 40.56 MHz. The contact time was $1 \mathrm{~ms}$ and a 90" pulse width of $6.8 \mathrm{1s}$, a pulse delay of $150 \mathrm{~ms}$ and a line broadening between 200 and $400 \mathrm{~Hz}$ were applied. Between 1 and $3 ! 10^{6}$ scans were accumulated at a magic-angle spin-

ning speed of $5.5 \mathrm{kHz}$. A ramped ${ }^{1} \mathrm{H}$-pulse starting at
$100 \%$ and decreasing to $50 \%$ of the maximal power was used during contact time (1 ms) in order to circumvent Hartmann-Hahn mismatches (Cook et al., 1996; Peersen et al., 1993). The chemical shift was standardized to the nitromethane scale $(0 \mathrm{ppm})$ and adjusted using ${ }^{15} \mathrm{~N}$ labelled glycine ()347.6 ppm). The assignment of the different integrals was performed according to Witanowski et al. (1993).
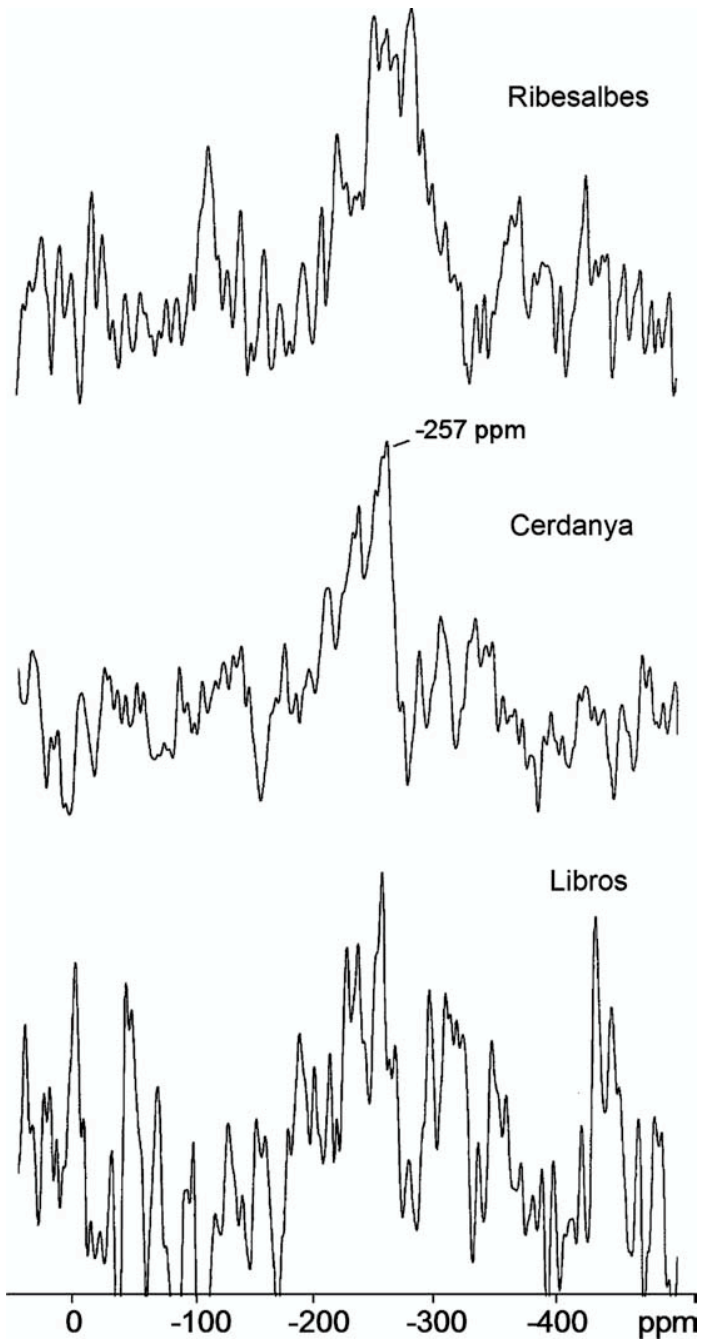

Fig. 1. Solid state ${ }^{15} \mathrm{~N}$ NMR spectra of kerogens from: (a) Ribesalbes; (b) Cerdanya; (c) Libros. 


\section{Results and discussion}

The CPMAS ${ }^{15} \mathrm{~N}$ NMR spectra of the selected Tertiary S-rich kerogens are shown in Fig. 1. Although the signal to noise ratio is very low, due to the low $\mathrm{N}$ concentration in the samples (N/C from 0.007 to 0.042 ; Table 1), it is clear that they exhibit intensity in the chemical shift region between )250 and )285 ppm, characteristic of amide structures. A shoulder is seen in the region of pyrrolic N ()145 to )240 ppm) in the spectra. Therefore, the spectra indicate that amide functional groups, which are normally highly susceptible to chemical and microbiological degradation, are part of the organic nitrogen in the kerogens. It has been previ-

Ribesalbes
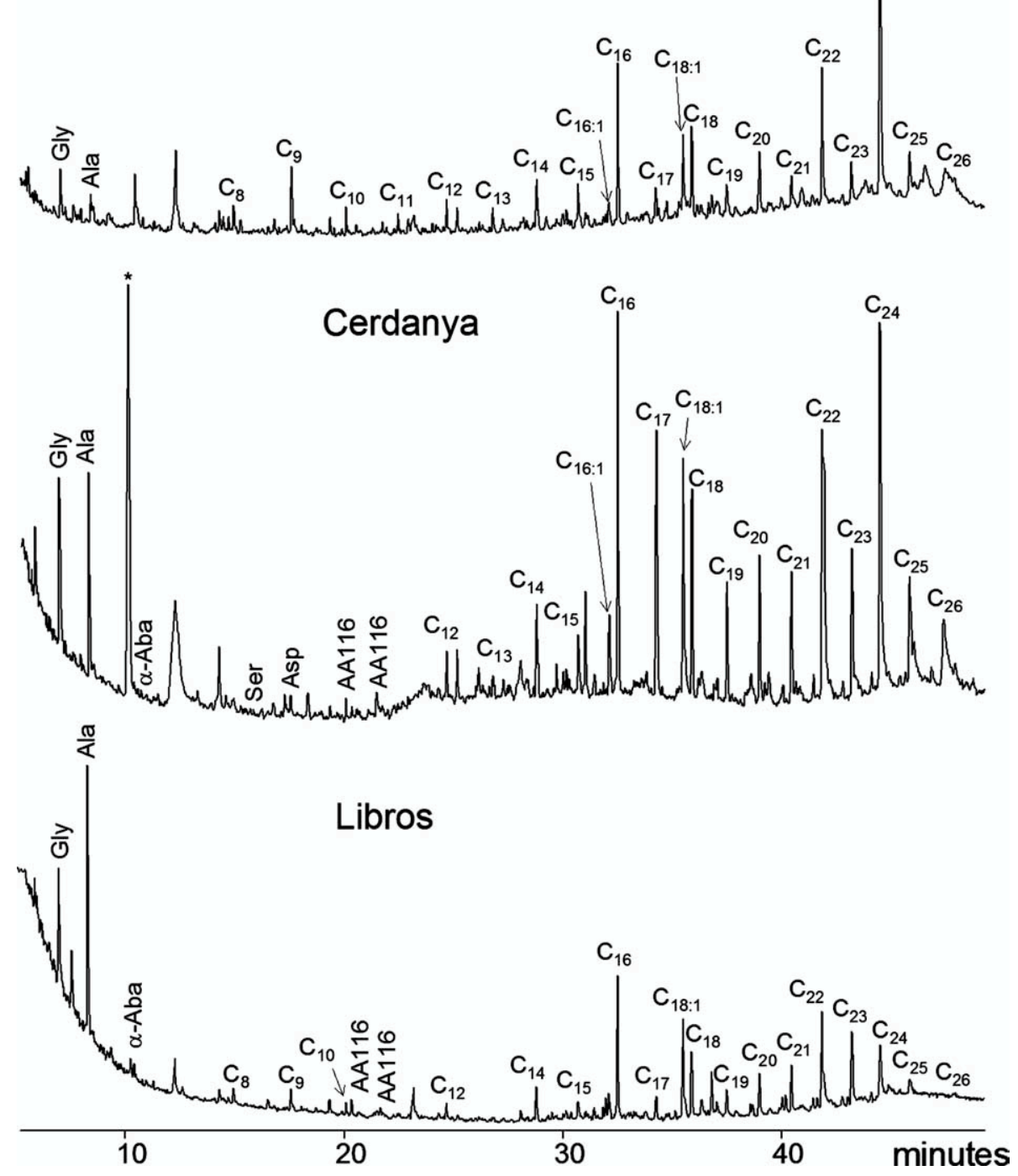

Fig. 2. TIC chromatogram of products released after pyrolysis in the presence of TMAH from the Ribesalbes, Cerdanya and Libros kerogens. Gly: glycine; Ala: alanine; a-Aba: a-aminobutyric acid; Ser: serine; Asp: aspartic acid; AA116 amino acid derivatives with base peak at m/z 116 similar to those detected by Riboulleau et al. (2002); $C_{n}$ refers to the series of fatty acids (as methyl esters); *: unknown. 
ously proposed that the amide $\mathrm{N}$ found in kerogens may derive from a refractory biopolymer composed of long chain alkyl amides (Derenne et al., 1993). Refractory chitinous residues (Stankiewicz et al., 1997) and peptidoglycans, which are a product of bacterial metabolism (Nyberg et al., 2001), might also explain the existence of amide $\mathrm{N}$ in these samples. Alternatively, such amides may derive from protein-derived peptide structures entrapped within the kerogen network. However, the survival of proteinaceous moieties in geological materials is surprising since they would be expected to be rapidly mineralized by microorganisms during the early stages of sediment formation.

In order to reveal the nature of the amide $\mathrm{N}$ revealed by ${ }^{15} \mathrm{~N}$ NMR and to know whether it could be assigned to peptide-like material entrapped within the kerogen network, the samples were analysed using pyrolysis in the presence of TMAH.

Fig. 2 shows the chromatogram of the compounds released from the kerogens after pyrolysis in the presence of TMAH. The chromatograms are dominated by peaks corresponding to fatty acids (as methyl esters) and amino acid derivatives. The fatty acid series consists mainly of $\mathrm{C}_{10}-\mathrm{C}_{26}$ monocarboxylic acids with an even-overodd carbon atom number predominance and a bimodal dis- tribution with maxima at $\mathrm{C}_{16}$ and $\mathrm{C}_{22}$ or $\mathrm{C}_{24}$, and con- tains unsaturated compounds $\left(\mathrm{C}_{16: 1}\right.$ and $\left.\mathrm{C}_{18: 1}\right)$, reflecting a contribution from living organisms and its highly aliphatic nature. The aliphatic acids may be chemically bound to the macromolecular network via sterically- protected, and hence, non-hydrolysable ester bonds (del Rlo et al., 1995; Gonzalez-Vila et al., 2001) and may be inherited directly from living organisms at an early stage of sedimentation (Kawamura and Ishiwatari, 1985).

Further, relatively high amounts of amino acid derivatives were released after Py-TMAH. Most of the identified amino acid derivatives originate from cleavage of peptide bonds and subsequent methylation of the carboxylic and the amino groups (Knicker et al., 2001). The release of amino acids provides evidence complementary to the ${ }^{15} \mathrm{~N}$ NMR results shown above, which indicate the presence of peptide materials in the samples. The released amino acids are dominated by glycine and alanine (as the N,N-dimethyl, methyl esters), which are especially abundant in the Cerdanya and Libros kerogens. Additionally, minor amounts of aspartic acid and serine, plus a non-protein amino acid, tentatively identified as a-amino-n-butyric acid and two compounds with a base peak at $\mathrm{m} / \mathrm{z} 116$, probably a-amino acid derivatives (Mongenot et al., 2001; Riboulleau et al., 2002), were detected in the Cerdanya kerogen. The kerogen from Libros released the highest amounts of amino acid derivatives compared to fatty acids while the kerogen from Ribesalbes released the lowest proportion, as indicated by the semiquantitative parameter $(\mathrm{Gly}+\mathrm{Ala}) / \mathrm{FaC}_{16} \quad$ (Table 1). Previous studies (Monge- not et al., 2001; Riboulleau et al., 2002) have shown release of amino acids from TMAH thermochemolysis of the methanol-eluted, non-acid fraction of the pyrolysate of a kerogen. However, this is the first time that such high quantities of amino acids have been released directly from kerogens upon Py-TMAH. It is interesting to note that the composition of amino acids released from the kerogens studied here is very similar to that found in other S-rich kerogens (Riboulleau et al., 2002) which also showed glycine and alanine as the most abundant amino acids. Glycine and alanine were also found to be the most abundant amino acids liberated after hydrolysis of the Pula kerogen (Nguyen and Harvey, 2003; Nguyen et al., 2003), which was consistent with the relative enrichment seen for these two nonpolar amino acids during the early diagenesis of the alga Botryococcus braunii. The high abundance seen for glycine and alanine in these and other kerogens can be explained as they are common diagenetic degradation products of other amino acids (Riboulleau et al., 2002).

Several mechanisms have been proposed to explain the survival of labile organic compounds such as peptide-like moieties in geological materials. It is widely accepted that labile compounds can be protected from microbiological decay via absorption to clay minerals (Hedges and Keil, 1995; Keil et al., 1994). According to this mechanism, labile materials are adsorbed on to mineral surfaces and stabilized by incorporation into mineral pores (mesopores) that are too small to allow entry and/or effective enzyme function. On the other hand, hydrophobic and hydrogen-bond interactions with other refractory organic materials in the sediment have also been proposed as major forces for the stabilization of nitrogen in sediments that offers protection from degradation. Peptide-like moieties may be effectively protected from degradation by encapsulation in the network of refractory biopolymers, such as the highly aliphatic biopolymer known as algaenan (Knicker and Hatcher, 1997; Knicker et al., 2001; Nguyen et al., 2003; Nguyen and Harvey, 2003). This encapsulation process may sterically protect peptides from enzymatic attack via intimate association with refractory, macromolecular material and can partly explain the fate of generally labile nitrogen in geological deposits. A preservation mechanism for the survival of protein-derived materials in humic substances, based on physical protection from highly aliphatic refractory substances in soil has also been proposed (Knicker and Hatcher, 1997; Zang et al., 2000; Knicker et al., 2001).

The present work supports the previous studies (Mongenot et al., 2001; Riboulleau et al., 2002; Nguyen and Harvey, 2003) that suggested that the survival of amino acids within an organic matrix is probably rather common in kerogen, especially glycine and alanine (part of which may arise from degradation of other amino acids, as stated above). Then, it is likely that these 
non-polar aliphatic amino acid components have stronger hydrophobic interactions with the paraffinic network than the fragments that have a higher content on polar amino acids. During kerogen formation, the paraffinic hydrocarbon moieties in the kerogen network may encapsulate the already closely associated aliphatic amino acid fragments and subsequently protect them from chemical and/or microbiological degradation. In addition, Mongenot et al. (2001) considered that protection might also be afforded by encapsulation into S-rich macromolecules and that the efficiency of encapsulation might be increased by the presence of sulfur links. The identification of relatively high amounts of amino acids released from the high sulfur Ribesalbes, Cerdanya and Libros kerogens seems to suggest that encapsulation into aliphatic structures in S-rich kerogens may at least partly explain the survival of peptide moieties in these geopolymers, as suggested by Riboulleau et al. (2002) for similar highly aliphatic S-rich kerogens.

\section{Conclusions}

Analysis using solid-state ${ }^{15} \mathrm{~N}$ NMR has shown that part of the refractory organic nitrogen in a series of Tertiary lacustrine S-rich kerogens corresponds to amide groups. Moreover, the release of amino acids after pyrolysis in the presence of TMAH demonstrated that the refractory organic nitrogen in these kerogens corresponds mostly to peptide-like moieties. Because peptide structures are generally considered as being highly sensitive to diagenetic degradation, an encapsulation mechanism within the refractory organic matter has been proposed to explain the survival of these structures, although the influence of other mechanisms such as interaction with the mineral matter cannot be completely excluded. However, the highly aliphatic character of the selected kerogens, as well as the release of both fatty acids and amino acids after Py/TMAH, supports the encapsulation process. The efficiency of encapsulation might also be increased by the presence of sulfur links in these S-rich kerogens.

\section{Acknowledgements}

J. Basas is acknowledged for the kerogen isolation. We are grateful to three anonymous reviewers for their comments.

\section{References}

Anadon, P., Roca, E., 1996. Geological setting of the Tertiary basins of Northeast Spain. In: Friend, P.F., Dabrio, C.
(Eds.), Tertiary Basins of Spain. Cambridge University Press, pp. 43-48.

Anadøn, P., Cabrera, L., Julia, R., Roca, E., Rosell, L., 1989. Lacustrine oil shale basins in tertiary grabens from NE Spain (Western European rift system). Record of lacustrine basins and their environmental signals. Palaeogeography, Palaeoclimatology and Palaeocology 70, 7-28.

Challinor, J.M., 1989. The scope of pyrolysis/methylation reactions. Journal of Analytical and Applied Pyrolysis 20 , $15-24$.

Clifford, D.J., Carson, D.M., McKinney, D.E., Bortiatynski, J.M., Hatcher, P.G., 1995. A new rapid technique for the characterization of lignin in vascular plants: thermochem- olysis with tetramethylammonium hydroxide (TMAH). Organic Geochemistry 23 (2), 169175.

Cook, R.L., Langford, C.H., Yamdagni, R., Preston, C.M., 1996. A Modified cross-polarization magic angle spinning

${ }^{13} \mathrm{C}$ NMR procedure for the study of humic materials. Analytical Chemistry 68, 3979-3986.

Derenne, S., Largeau, C., Taulelle, F., 1993. Occurrence of nonhydrolysable amides in the macromolecular constituent of Scenedesmus quadricauda cell wall as revealed by ${ }^{15} \mathrm{~N}$ NMR: Origin of n-alkylnitriles in pyrolysates of ultralaminae- containing kerogens. Geochimica et Cosmochimica Acta 57, 851-857.

Derenne, S., Knicker, H., Largeau, C., Hatcher, P.G., 1998. Timing and mechanism of changes in nitrogen functionality during biomass fossilization. In: Stankiewicz, B.A., van Bergen, P.F. (Eds.), Nitrogen-containing Macromolecules in the Bio- and Geosphere. ACS Symposium Series, vol. 707 , pp. 243-253.

de las Heras, X., Grimalt, J., Albaiges, J., Julia, R., Anadøn, P., 1989. Origin and diagenesis of the organic matter in miocene freshwater lacustrine phosphates (Cerdanya Basin, Eastern Pyrenees). Organic Geochemistry 14, 667-677.

Garcette-Lepecq, A., Derenne, S., Largeau, C.1., Bouloubassi, I., Saliot, A., 2001. Thermally assisted hydrolysis and methylation of kerogen-like organic matter in a recent sediment off the Danube delta (northwstern Black Sea). Journal of Analytical and Applied Pyrolysis 61, 147-164.

Gonzalez-Vila, F.J., Ambless, A., del Rlo, J.C., Grasset, L., 2001. Characterisation and differentiation of kerogens by pyrolytic and chemical degradation techniques. Journal of Analytical and Applied Pyrolysis 58-59, 315-328.

Hedges, J.I., Keil, R.G., 1995. Sedimentary organic matter preservation: an assessment and speculative synthesis. Marine Chemistry 49, 81-115.

Huang, Z.H., Wang, J., Gage, D.A., Watson, J.T., Sweeley, C.C., Husek, P., 1993. Characterization of Nethoxycar- bonyl ethyl esters of amino acids by mass spectrometry. Journal of Chromatography A 635, 271-281.

Kawamura, K., Ishiwatari, R., 1985. Conversion of sedimentary fatty acids to extractable (unbound + bound) to tightly bound form during mild heating. Organic Geochemistry 8, 197-201.

Keil, R.G., Montlucon, D.B., Prahl, F.G., Hedges, J.I., 1994. Sorptive preservation of labile organic matter in marine sediments. Nature 370, 549-552.

Knicker, H., 2000. Solid-state 2-D double cross polarization magic angle spinning ${ }^{15} \mathrm{~N} \quad{ }^{13} \mathrm{C}$ NMR spectroscopy on degraded algal residues. Organic Geochemistry 31, 337-340. 
Knicker, H., Hatcher, P., 1997. Survival of protein in an organic-rich sediment: possible protection by encapsulation in organic matter. Naturwissenschaften 84, 231-234.

Knicker, H., del Rlo, J.C., Hatcher, P.G., Minard, R.D., 2001. Identification of protein remnants in insoluble geopolymers using TMAH thermochemolysis/GC-MS. Organic Geochemistry 32, 397-409.

de Leeuw, J.W., Baas, W., 1993. The behaviour of esters in the presence of tetramethylammonium salts at elevated temperatures: flash pyrolysis or flash chemolysis? Journal of Analytical and Applied Pyrolysis 26, 175-184.

Martln, F., Gonzalez-Vila, F.J., del Rlo, J.C., Verdejo, T., 1994. Pyrolysis derivatization of humic substances. 1 Pyrolysis of fulvic acids in the presence of tetramethylam- monium hydroxide. Journal of Analytical and Applied Pyrolysis 28, 71-80.

Mongenot, Th., Riboulleau, A., Garcette-Lepecq, A., Derenne, S., Pouet, Y., Baudin, F., Largeau, C., 2001. Occurrence of proteinaceous moieties in S- and O-rich Late Tithonian kerogen (Kashpir oil shales, Russia). Organic Geochemistry 32, 199-203.

Nguyen, R.T., Harvey, H.R., 2003. Preservation via macromolecular associations during Botryococcus braunii decay: proteins in the Pula kerogen. Organic Geochemistry 34, 1391-1403.

Nguyen, R.T., Harvey, H.R., Zang, X., van Heemst, J.D.H., Hetenyi, M., Hatcher, P.G., 2003. Preservation of algaenan and proteinaceous material during the oxic decay of Botryococcus braunii as revealed by pyrolysisgas chroma- tography/mass spectroscopy and ${ }^{13} \mathrm{C}$ NMR spectroscopy. Organic Geochemistry 34, 483-497.

Nyberg, J., Csap§, J., Malmgren, B.A., Winter, A., 2001. Changes in the $\mathrm{D}-$ and $\mathrm{L}$-content of aspartic acid, glutamic acid, and alanine in a scleractinian coral over the last 300 years. Organic Geochemistry 32, 623-632.

Patience, R.L., Baxby, M., Bartle, K.D., Rees, A.G.W., Rowland, S.J., 1992. The functionality of organic nitrogen in some recent sediments from the Peru upwelling region. Organic Geochemistry 18, 161-169.

Peersen, O.B., Wu, X., Kustanovich, I., Smith, S.O., 1993. Variable-amplitude cross-polarization MAS NMR. Journal of Magnetic Resonance 104, 334-339.

Riboulleau, A., Mongenot, T.h., Baudin, F., Derenne, S., Largeau, C., 2002. Factors controlling the survival of proteinaceous material in Late Tithonian kerogens (Kashpir oil shales, Russia). Organic Geochemistry 33, 11271130.

del Rlo, J.C., Martın, F., Gonzalez-Vila, F.J., Verdejo, T., 1995. Chemical structural investigations of asphaltenes and kerogens by pyrolysis-methylation. Organic Geochemistry 23, 1009-1022.

del Rlo, J.C., MartIn, F., Gonzalez-Vila, F.J., 1996. Thermally assisted hydrolysis and alkylation as a novel pyrolytic approach for the structural characterization of natural biopolymers and geomacromolecules. Trends in Analytical Chemistry 15, 70-79.

del Rlo, J.C., Hatcher, P.G., 1998. Analysis of aliphatic biopolymers using thermochemolysis with tetramethylammonium hydroxide (TMAH) and gas chromatography-mass spectrometry. Organic Geochemistry 29, 1441-1451.

del Rlo, J.C., McKinney, D.E., Knicker, H., Nanny, M.A., Minard, R.D., Hatcher, P.G., 1998. Structural characterization of bio- and geo-macromolecules by off-line thermochemolysis with tetramethylammonium hydroxide. Journal of Chromatography A 823, 433-448.

Saiz-Jimenez, C., 1994. Analytical pyrolysis of humic substances: Pitfalls, limitations, and possible solutions. Environmental Science and Technology 28, 1773-1778.

Simoneit, B.R.T., Vuchev, V.T., Grimalt, J.O., 1986. Organic matter along the sedimentary sequences of the continental margin. In: Hinz et al. (Ed.), Leg 79 sites 545 and 547. Initial Reports of the Deep Sea Drilling Project. vol. 79. US Government, Printing Office, Washington, DC, pp. 807824.

Schulten, H.-R., Schnitzer, M., 1997. The chemistry of soil organic nitrogen: a review. Biological Fertilizer Soils 26, 115.

Stankiewicz, B.A., Briggs, D.E.G., Evershed, R.P., Duncan, I.J., 1997. Chemical preservation of insect cuticle from the Pleistocene asphalt deposits of California, USA. Geochimica et Cosmochimica Acta 61, 2247-2252.

Witanowski, M., Stefaniak, L., Webb, G.A., 1993. Nitrogen NMR Spectroscopy. Academic Press, London.

Zang, X., van Heemst, J.D.H., Dria, K.J., Hatcher, P.G., 2000. Encapsulation of protein in humic acid from a histosol as an explanation for the occurrence of organic nitrogen in soil and sediment. Organic Geochemistry 31, 679-695. 